\title{
Penerapan Model Pembelajaran Kooperatif Tipe Teams Games Tournament untuk Meningkatan Hasil Belajar Siswa Kelas VI pada Mata Pelajaran Matematika di SDN No.058/XI Koto Dumo
}

\author{
Zainal Abidin ${ }^{1}$ \\ Guru di SDN. No. 058/XI Koto Dumo ${ }^{1}$ \\ Kecamatan Tanah Kampung, Kota Sungai Penuh, Provinsi Jambi
}

\begin{abstract}
This study aims to improve the learning outcomes of sixth grade students at SDN. No. 058/XI Koto Dumo on mathematics subject, especially on integer operation material by using cooperative learning model of Teams Games Tournament type. This research is a classroom action research conducted in three cycles and each cycle is done with four activities, namely planning, implementation, observation, and reflection. This study was conducted from August to November of 2016. The study involved 16 sixth graders. Data were collected by observation and test. Data were analyzed by using descriptive analysis and simple statistical test. The results showed that the activities and learning outcomes of students before and after the given action (Cycle I, Cycle II, and Cycle III) improved. Thus, the use of cooperative learning model type Teams Games Tournament in SDN. No. 058/XI Koto Dumo can improve student learning outcomes in mathematics subjects, especially on the subject matter of integer counting operations.
\end{abstract}

Keywords: classroom action research, elementary school, learning outcomes, mathematics subjects, Teams Games Tournament

\section{PENDAHULUAN}

Pendidikan adalah usaha sadar dan terencana untuk mewujudkan suasana belajar dan proses pembelajaran agar peserta didik secara aktif mengembangkan potensi dirinya untuk memiliki kekuatan spiritual keagamaan, pengendalian diri, kepribadian, kecerdasan, akhlak mulia, serta keterampilan yang diperlukan dirinya, masyarakat, bangsa dan negara. Keberhasilan pendidikan di sekolah, khususnya sekolah dasar bergantung pada banyak faktor, salah satunya adalah guru. Guru di sekolah dasar bertugas untuk mendidik, mengajar, membimbing, mengarahkan, melatih, menilai, dan mengevaluasi peserta didik pada tingkat Sekolah Dasar.

Hasil pengamatan guru di SDN. No. 058/XI Koto Dumo menunjukkan bahwa proses pembelajaran masih monoton, hal ini terlihat dari metode dalam proses pembelajaran yang digunakan oleh guru hanya menceramahi peserta didik di depan kelas. Proses pembelajaran hanya berpusat pada guru. Guru sebagai penyampai materi atau penceramah dan siswa sebagai pendengar, sehingga interaksi antara siswa dengan guru sangatlah kurang, karena guru memiliki peran yang dominan. Dengan model pembelajaran yang demikian tentunya siswa tidak dapat mengembangkan potensi yang ada dalam dirinya. Disamping itu, proses belajar mengajar selalu diawali dengan penjelasan materi di depan kelas beserta contoh soal dan latihan. Siswa selalu disuruh untuk mencatat apa yang ditulis oleh guru dan tidak melibatkan siswa dalam penyelesaian masalah. Guru biasanya meminta siswa mengerjakan soal-soal di buku latihan kemudian dikumpul dan begitu seterusnya. Hal ini tentunya sangatlah mempengaruhi hasil belajar siswa yang belum sesuai dengan yang diharapkan yaitu masih di bawah standar ketuntasan yang ditetapkan.

Guru masih kesulitan untuk menyampaikan materi operasi hitung 
bilangan bulat. Kesulitan guru itu terlihat dari bagaimana cara guru menyampaikan materi tersebut. Berbagai cara telah dilakukan guru agar pembelajaran matematika dirasa mudah dan menarik bagi siswa, tetapi terkadang cara yang diterapkan oleh guru dalam proses pembelajaran kurang tepat sehingga menimbulkan masalah bagi siswa dalam memahami konsep materi yang diajarkan. Cara yang dilakukan guru antara lain yaitu memberikan sangsi apabila tidak bisa mengerjakan soal yang diberikan, memberikan permainan menghafal perkalian atau pembagian dasar, tetapi hal ini tidak diperhatikan oleh seluruh siswa.

Secara umum, proses pembelajaran matematika masih memiliki kualitas rendah dimana guru kurang belum bisa menarik perhatian siswa yang ditandai dengan aktivitas belajar mengajar masih kurang memuaskan. Pemilihan model pembelajaran yang kurang sesuai dengan materi pelajaran yang menyebabkan siswa sulit dalam memahami materi yang disampaikan dalam pembelajaran MTK. Siswa hanya pasif mendengarkan dan mencatat saja sehingga siswa merasa jenuh dan bosan memahami materi, karena kegiatan pembelajaran yang dilakukan cenderung monoton dan tidak bervariasi. Rendahnya nilai hasil belajar siswa khususnya pada materi "operasi hitung bilangan bulat" yang selalu dibawah standar KKM (Kriteria Ketuntasan Minimal) yaitu 70,00. Hanya 6 siswa dari 16 siswa keseluruhan yang mendapat nilai lebih besar dari 70,00. Persentase siswa yang menguasai operasi hitung bilangan bulat hanya sebesar $37,50 \%$ yang dinyatakan berhasil dari jumlah siswa kelas VI. Nilai ini sangat jauh dari harapan, oleh karena itu diperlukan tindakan kelas yang tepat agar nantinya pada akhir penelitian terjadi perubahan atau peningkatan hasil belajar khususnya pada materi operasi hitung bilangan bulat.

Dalam memperbaiki sistem pembelajaran yang cenderung membuat siswa tidak memahami konsep dari materi yang diajarkan yaitu operasi hitung bilangan bulat, maka guru harus mengetahui aspek-aspek apa saja yang harus diperbaiki. Karena pola pengajaran yang salah dapat berakibat tidak baik bagi diri siswa maupun hasil belajar siswa itu sendiri. Guru hendaknya membuat dan melaksanakan rencana pelaksanaan pembelajaran agar menghasilkan satu kegiatan pembelajaran yang berlangsung secara interaktif, inspiratif, menyenangkan, menantang, memotivasi peserta didik untuk berpartisipasi aktif dan tentunya dapat meningkatkan hasil belajar siswa.

Salah satu cara yang dapat dilakukan adalah mengubah model pembelajaran yang digunakan. Model pembelajaran adalah kerangka konseptual yang melukiskan prosedur yang sistematik dalam mengorganisasikan pengalaman belajar untuk mencapai tujuan belajar tertentu, dan berfungsi sebagai pedoman bagi para perancang pembelajaran dan para pengajar dalam merencanakan aktivitas belajar mengajar (Trianto, 2007). Model pembelajaran juga dapat diartikan sebagai kerangka konseptual yang melukiskan prosedur sistematis dalam mengorganisasikan pengalaman belajar untuk mencapai tujuan belajar (Suprijono, 2012). Model pembelajaran mengacu pada pendekatan yang akan digunakan, termasuk di dalamnya tujuan- tujuan pembelajaran, tahap-tahap dalam kegiatan pembelajaran, lingkungan pembelajaran, dan pengelolaan kelas. Dalam penerapannya, model pembelajaran harus dilakukan sesuai dengan kebutuhan siswa, karena masingmasing model pembelajaran memiliki tujuan, prinsip, dan tekanan yang berbedabeda. Guru boleh memilih model pembelajaran yang sesuai dan efisien untuk mencapai tujuan pendidikannya (Rusman, 2010).

Model pembelajaran yang dinilai cocok dan relevan untuk meningkatkan hasil belajar siswa pada mata pelajaran matematika adalah model pembelajaran 
kooperatif tipe Teams Games Tournament (TGT). Model pembelajaran kooperatif adalah suatu model pembelajaran yang mana siswa bekerja dalam kelompokkelompok kecil secara kolaboratif yang anggotanya terdiri atas 4 sampai 5 orang dengan struktur kelompoknya yang bersifat heterogen. Keberhasilan belajar dari kelompok bergantung pada kemampuan dan aktivitas anggota kelompok, baik secara individual maupun secara kelompok (Solihatin dan Raharjo, 2007). Menurut Rusman (2010), TGT adalah salah satu tipe model pembelajaran kooperatif yang menempatkan siswa dalam kelompokkelompok belajar yang beranggotakan 5 sampai 6 orang siswa yang memiliki kemampuan, jenis kelamin dan suku atau ras yang berbeda.Guru menyajikan materi, dan siswa bekerja dalam kelompok mereka masing-masing. Dalam kerja kelompok guru memberikan LKS kepada setiap kelompok. Tugas yang diberikan dikerjakan bersama-sama dengan anggota kelompoknya. Apabila ada dari anggota kelompok yang tidak mengerti dengan tugas yang diberikan, maka anggota kelompok yang lain bertanggung jawab untuk memberikan jawaban atau menjelaskannya, sebelum mengajukan pertanyaannya tersebut kepada guru.

Berdasarkan pemaparan tersebut, guru bermaksud untuk menyelenggarakan penelitian tindakan kelas yang bertujuan untuk meningkatkan hasil belajar siswa kelas VI di SDN. No. 058/XI Koto Dumo dalam operasi hitung bilangan bulat dengan menggunakan model pembelajaran kooperatif tipe Teams Games Tournament.

\section{METODE PENELITIAN}

Penelitian ini merupakan penelitian tindakan kelas yang dilakukan di SDN. No. 058/XI Koto Dumo, Kecamatan Tanah Kampung, Kota Sungai Penuh, Provinsi Jambi. Kegiatan penelitian ini dilaksanakan sejak bulan Agustus sampai dengan bulan November 2016. Kegiatan penelitian ini melibatkan 16 orang siswa Kelas VI di
SDN. No. 058/XI Koto Dumo yang terdiri atas 8 orang siswa yang berjenis kelamin perempuan dan 8 orang siswa yang berjenis kelamin laki-laki.

Penelitian tindakan kelas dilakukan dalam tiga siklus. Siklus I terdiri atas 3 pertemuan, Siklus II terdiri atas 3 pertemuan, dan Siklus III terdiri atas 2 pertemuan. Setiap siklus terdiri atas empat kegiatan, yaitu perencanaan, pelaksanaan, observasi, dan refleksi. Perencanaan tindakan adalah kegiatan mempersiapkan segala sesuatu yang akan dilakukan pada setiap siklus. Persiapan dilakukan mulai dari awal sampai persiapan di siklus terakhir. Pelaksanaan tindakan terdiri atas tiga kegiatan, yaitu kegiatan awal, kegiatan inti, dan kegiatan akhir. Observasi dilakukan untuk mengamati semua kegiatan yang berlangsung didalam kelas selama tindakan diberikan. Setiap akhir siklus diadakan evaluasi dengan tes tertulis. Refleksi terhadap hasil observasi akan dilakukan dalam dua tahapan yaitu setelah setiap selesai satu pertemuan setiap selesai satu siklus.

Data yang dikumpulkan merupakan data hasil belajar siswa. Data ini dikumpulkan melalui observasi dan tes. Selanjutnya, data yang telah dikumpulkan diolah dan dianalisis dengan menggunakan analisis deskriptif dan uji statistic sederhana. Kriteria keberhasilan belajar siswa dengan menggunakan model pembelajaran kooperatif tipe TGT adalah siswa dianggap tuntas dalam belajar apabila siswa tersebut memenuhi Kriteria Ketuntasan Minimum yaitu 70,00. Selain itu, suatu kelas dianggap tuntas dalam belajar apabila sekurang kurangnya $85,00 \%$ siswa di kelas tersebut mencapai daya serap di atas $70,00 \%$.

\section{HASIL DAN PEMBAHASAN Siklus I}

Penelitian siklus I dilaksanakan sebanyak 3 kali pertemuan yaitu pada tanggal 1 Agustus 2016, 10 Oktober 2016, dan 12 November 2016 di kelas VI SDN 
058/XI Koto Dumo. Kegiatan penelitian terdiri atas empat kegiatan, yaitu: 1) Perencanaan, 2) Pelaksanaan, 3) Observasi, dan 4) Refleksi.

Perencanaan tindakan adalah kegiatan mempersiapkan segala sesuatu yang akan dilakukan pada setiap siklus. Persiapan dilakukan mulai dari awal sampai persiapan di siklus terakhir. Kegiatan diawali dengan analisis kurikulum. Peneliti melakukan analisis kurikulum untuk mengetahui kompetensi dasar yang akan dicapai kepada siswa dengan menggunakan pembelajaran kooperatif tipe TGT. Kegiatan dilanjutkan dengan membuat Rencana Pelaksanaan Pembelajaran, membuat

SkenarioPembelajaran, membuat Lembar Kerja Siswa, membuat Lembar Observasi, dan membuat Lembar Tes.

Pelaksanaan tindakan terdiri atas tiga kegiatan, yaitu kegiatan awal, kegiatan inti, dan kegiatan akhir. Pada, kegiatan awal, guru melakukan apersepsi, guru menyampaikan tujuan pembelajaran yang harus dicapai mengenai materi yang akan dipelajari, dan guru memberikan motivasi tentang pentingnya mempelajari materi yang akan dipelajari dalam kehidupan sehari-hari dengan memberikan contoh yang kongkrit. Kegiatan inti dilakukan dengan tiga tahapan, yaitu tahap eksplorasi, tahap elaborasi, dan tahap konfirmasi. Pada tahap Eksplorasi, guru memberikan beberapa pertanyaan kepada siswa tentang operasi hitung bilangan bulat untuk mengetahui seberapa besar pengetahuan yang dimiliki siswa mengenai materi yang akan dipelajari,guru menyampaikan materi pembelajaran yaitu operasi hitung bilangan bulat sesuai dengan kompetensi yang harus dicapai oleh siswa, siswa di dalam kelas dibagi menjadi beberapa kelompok yang masing-masingnya terdiri atas 4-5 anggota kelompok. Tiap kelompok mempunyai anggota yang heterogen, baik jenis kelamin, ras, etnik, maupun kemampuan akademiknya. Pada tahap elaborasi, guru memberikan tugas kepada kelompok dengan menggunakan lembar kerja yang sesuai dengan materi yang dipelajari. Kemudian setiap anggota kelompok saling membantu dalam menguasai materi pelajaran yang telah diberikan melalui tanya jawab atau diskusi antar sesama anggota kelompok. Guru harus memastikan bahwa seluruh anggota kelompok telah menguasai materi tersebut. Guru menempatkan para siswa ke dalam 4 meja turnamen yang telah disediakan, sesuai dengan tingkat penguasaan siswa terhadap materi yang sebelumnya telah didiskusikan dan diselesaikan di dalam kelompoknya masing-masing. Dalam satu meja turnamen terdiri dari 4 siswa dari masing-masing kelompok yang berbeda. Siswa disetiap meja turnamen bersaing untuk memperoleh skor terbanyak menjawab pertanyaan yang telah disediakan dalam boks kartu bernomor yang berisi pertanyaanpertanyaan yang berkaitan dengan materi yang dipelajari. Pada Tahap konfirmasi, tiap siswa dan tiap kelompok di beri skor atas penguasaannya terhadap materi pelajaran. Dan kepada siswa secara individual atau kelompok yang meraih prestasi tinggi atau skor yang sempurna akan diberi penghargaan. Kegiatan Akhir terdiri atas guru memberikan umpan balik dengan melakukan tanya jawab tentang materi yang telah dipelajari, guru membantu siswa untuk menyimpulkan materi yang telah dipelajari, dan guru memberikan tindak lanjut dengan memberi tugas kepada siswa.

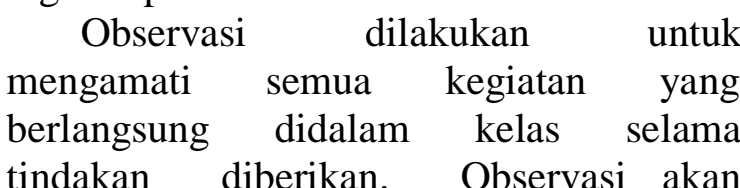
dilakukan oleh peneliti dengan menggunakan lembar observasi yang telah disediakan, observasi akan dilaksanakan selama proses pembelajaran. Indikator yang akan diobservasi yaitu semangat siswa dalam belajar, keaktifan siswa dalam belajar, kerja sama dalam kelompok, kemampuan dalam memberikan tanggapan, kemampuan siswa dalam memecahkan masalah, dan kemampuan dalam membuat 
kesimpulan. Hasil pengamatan aktivitas disajikan pada Tabel 1. siswa selama kegiatan pembelajaran

Tabel 1 Hasil observasi aktivitas siswa Siklus I

\begin{tabular}{clccccc}
\hline \multirow{2}{*}{ No } & \multicolumn{1}{c}{ Indikator } & \multicolumn{2}{c}{ Pertemuan ke- (\%) } & \multirow{2}{*}{ Jumlah } & Persentase \\
& & I & II & III & & $(\%)$ \\
\hline 1 & Mengerjakan LKS dalam kelompok & 59,37 & 65,62 & 68,75 & 193,74 & 64,58 \\
2 & Aktif berdiskusi dalam kelompok & 65,62 & 68,75 & 73,43 & 207,8 & 69,26 \\
& Aktif memberikan pertanyaan / & 56,25 & 65,62 & 73,43 & 195,3 & 65,10 \\
& tanggapan & & & & & \\
4 & Aktif menjawab / merespon pertanyaan & 59,67 & 65,62 & 68,75 & 194,01 & 64,67 \\
5 & Mengerjakan tugas yang diberikan oleh & 67,18 & 70,31 & 73,43 & 210,89 & 70,29 \\
& guru & & & & & \\
& Jumlah & 308,09 & 335,92 & 357,79 & 1001,74 & 333,90 \\
& Persentase rata-rata & 61,61 & 67,18 & 71,55 & 66,78 & 66,78
\end{tabular}

Hasil penelitian yang disajikan pada Tabel 1 menunjukkan bahwa aktivitas belajar siswa pada siklus I mengalami kenaikan pada setiap pertemuannya, maupun secara keseluruhannya. Hal ini dapat dilihat dari hasil pengamatan aktivitas siswa yang paling menonjol yaitu aktivitas siswa mengerjakan tugas yang diberikan oleh guru yaitu 70,29 \%. Sedangkan aktivitas siswa yang masih rendah yaitu mengerjakan lembar kerja siswa sebesar $64,58 \%$, menjawab pertanyaan/merespon pertanyaan sebesar 64,67\%, siswa memberikan pertanyaan/tanggapan sebesar $65,10 \%$ dan aktif berdiskusi di dalam kelompok sebesar 69,26 \%.Dari hasil observasi yang telah didapatkan menunjukkan bahwa aktivitas siswa pada siklus I ini masih kurang dikarenakan siswa masih belum terbiasa belajar dalam kelompok.

Setiap akhir siklus, guru mengadakan evaluasi dengan tes tertulis. Tes dilakukan untuk melihat dan menentukan kemampuan murid menguasai materi operasi hitung pada bilangan bulat yang telah disajikan pada soal-soal pada lembar kerja siswa yang sudah di persiapkan. Hasil evaluasi siswa pada siklus I disajikan pada Tabel 2.

Tabel 2 Hasil tes siswaSiklus I

\begin{tabular}{clc}
\hline No & \multicolumn{1}{c}{ Hal yang Diamati } & Hasil Evaluasi siklus I \\
\hline 1 & Rata-rata kelas & 61,25 \\
2 & Banyak siswa yang tuntas & 8 \\
3 & Banyak siswa yang belum tuntas & 8 \\
4 & Persentase siswa yang tuntas & $50 \%$ \\
5 & Persentase siswa yang belum tuntas & $50 \%$ \\
\hline
\end{tabular}

Hasil belajar siswa pada akhir siklus I, siswa yang memperoleh nilai lebih dari atasu sama dengan 70,00 atau siswa yang tuntas hanya 8 orang atau $50,00 \%$ dan nilai rata-rata kelas baru mencapai 61,25 ini berarti belum mencapai nilai ketuntasan yang telah ditetapkan yaitu 70,00\%.

Hasil penelitian menunjukkan bahwa adanya penghargaan atas poin perkembangan yang diperoleh setiap masing-masing kelompok dengan predikat Good Team dengan kriteria poin 30 - 40 dan prediket Great Team dengan kriteria poin 40-45. Hasil skor yang diperoleh oleh masing-masing kelompok dapat dilihat pada Tabel 3. 
Tabel 3 Hasil tes siswa per kelompok Siklus I

\begin{tabular}{clcccccc}
\hline \multirow{2}{*}{ No } & Nama & \multicolumn{2}{c}{ Akumulasi Point Turnamen } & \multirow{2}{*}{ Jumlah } & Rata- & Predikat \\
& Kelompok & I & II & II & & & \\
\hline 1 & Matahari & 50 & 45 & 40 & 135 & 45 & Great Team \\
2 & Bintang & 35 & 27,5 & 35 & 97,5 & 32,5 & Good Team \\
3 & Bulan & 37,5 & 40 & 37,5 & 115 & 38,3 & Good Team \\
4 & Pelangi & 40 & 50 & 42,5 & 132,5 & 44,2 & Great Team \\
\hline
\end{tabular}

Hasil penelitian siklus 1 menunjukkan bahwa hasil belajar siswa pada materi operasi hitung bilangan bulat dengan menggunakan model kooperatif tipe TGT meningkat, namun masih belum optimal. Hal ini ditunjukkan dari kegiatan guru yang belum maksimal dalam mengelola kelas, sehingga mengakibatkan keaktifan siswa yang masih kurang baik, kerja sama siswa dalam kelompok yang kurang baik karena siswa masih belum terbiasa dengan kondisi belajar kelompok.Siswa sering bertanya dan berkomentar atas penjelasan dalam pengerjaan tugas kelompok ataupun dalam mengerjakan tugas individu karena penjelasan guru yang kurang baik. Penerapan model pembelajaran kooperatif yang belum efektif yang terlihat dari guru yang masih bingung terhadap apa yang harus dilakukan, sehingga kondisi siswa dalam belajar menjadi kurang kondusif. Hal ini mengakibatkan siswa menjadi ribut dan sering berjalan-jalan di dalam kelas.

Hasil refleksi menunjukkan bahwa materi operasi hitung bilangan bulat dengan menggunakan model kooperatif tipe TGT memberikan dampak yang positif terhadap peningkatan hasil belajar, tetapi hasil belajar pada siklus pertama ini masih di bawah ketuntasan klasikal yaitu 70,00\% dan siswa yang memperoleh nilai 70 hanya beberapa siswa saja. Hal ini ditunjukkan dari hasil belajar yang telah dilakukan pada siklus 1 yaitu hanya 8 siswa yang mencapai nilai ketuntasandengan persentase ketuntasan 50,00\%. Dengan demikian, di siklus II akan ditingkatkan kemampuan guru dalam melakukan pembelajaran dengan menggunakan model kooperatif tipe TGT dan menggunakan media pembelajaran yang lebih menarik yaitu dengan menggunakan garis bilangan dan kartu-kartu bernomor, serta meningkatkan motivasi siswa dengan menggunakan penghargaan berupa alat tulis.Guru juga harus memberi pemahaman kepada anggota kelompok yang belum memahami langkahlangkah pembelajaran kooperatif tipe TGT dan lebih membimbing kelompok yang mengalami kesulitan.

\section{Siklus II}

Penelitian siklus II dilaksanakan sebanyak 3 kali pertemuan yaitu pada tanggal 15 November 2016, 17 November 2016 dan 19 November 2016 di kelas VI SDN 058/XI Koto Dumo. Pada penelitian siklus II kegiatan yang dilakukan sama seperti pada siklus I yaitu dibagi dalam 4 (empat) kegiatan yaitu : 1) Perencanaan, 2) Pelaksanaan, 3) Observasi , dan 4) Refleksi.

Perencanaan tindakan adalah kegiatan mempersiapkan segala sesuatu yang akan dilakukan pada setiap siklus. Kegiatan perencanaan dilakukan dengan membuat Rencana Pelaksanaan Pembelajaran, membuat SkenarioPembelajaran, membuat Lembar Kerja Siswa, membuat Lembar Observasi, dan membuat Lembar Tes.

Pada siklus II ini, kegiatan awal yang dilakukan oleh guru adalah melakukan apersepsi yaitu guru meninjau kembali materi yang telah dipelajari yang berkaitan dengan materi yang akan dipelajari dengan memberikan pertanyaan tentang penjumlahan dan pengurangan bilangan bulat. Setelah melakukan apersepsi dan hampir seluruh siswa menanggapi apersepsi tersebut, kemudian guru menjelaskan tujuan pembelajaran dari materi yang akan 
dipelajari kepada siswa secara singkat. Selanjutnya guru memberikan motivasi kepada siswa dengan cara mengaitkan materi yang akan dipelajari dengan mencontohkan kegiatan yang biasa dilakukan siswa dalam kehidupan seharihari dan guru juga langsung memberikan penjelasan tentang petunjuk cara pembelajaran dengan menggunakan model pembelajaran kooperatif tipe TGT dan para siswa hanya mendengarkan penjelasan guru.

Pada kegiatan inti guru membagi siswa menjadi 4 kelompok yang anggota kelompoknya terdiri dari 4 orang dan anggota kelompok dibagi secara acak.Kemudian guru membimbing siswa untuk mengambil posisi tempat duduk berdasarkan kelompok yang sudah diatur posisinya oleh guru. Guru kemudian menjelaskan materi secara singkat dengan. Selanjutnya guru memberikan tugas kepada kelompok dengan menggunakan lembar kerja siswa yang mana pada setiap kelompok mendapat empat lembar kerja, kemudian setiap anggota kelompok mengerjakan tugas yang telah diberikan dengan saling bekerjasama dan saling membantu untuk menguasai materi, siswa harus mengumpulkan lembar kerja tersebut sesuai dengan waktu yang telah ditentukan. Pada kegiatan ini sudah terlihat bahwa siswa mau mengerjakan tugas, namun masih terlihat sedikit siswa yang hanya menyalin tugas temannya.Pada tahap ini guru mengamati kinerja siswa dalam kelompoknya masing-masing. Setelah tugasnya selesai dan telah dikumpulkan, kemudian guru memberikan game kepada siswa. Game dilakukan dengan cara siswa dibagi ke dalam 4 meja turnamen yang mana pada setiap meja terdiri dari 1 orang dari masing-masing kelompok sesuai dengan tingkat penguasaan siswa terhadap materi yang sebelumnya telah didiskusikan dan diselesaikan di dalam kelompoknya masing-masing. Dalam setiap meja turnamen disediakan pertanyaanpertanyaan yang harus dijawab oleh siswa dalam kartu-kartu bernomor yang berisi pertanyaan yang harus dijawab oleh siswa, dalam setiap meja turnamen terdapat 6 soal yang harus dijawab oleh siswa, skor yang diperoleh siswa dalam setiap meja kemudian dikumpulkan untuk menentukan kelompok mana yang memperoleh predikat tertinggi. Bagi kelompok yang memperoleh poin tinggi diberi reward berupa alat tulis. Pada tahap ini siswa siswa sudah terbiasa dengan langkah-langkah pembelajaran dengan meggunakan model TGT. Untuk mengetahui tingkat penguasaan siswa terhadap materi yang telah dipelajari guru memberikan evaluasi pada akhir siklus.

Pada kegiatan akhir guru memberikan umpan balik kepada siswa yaitu dengan cara memberikan pertanyaan kepada siswa tentang materi yang telah dipelajari, pada kegiatan ini siswa sudah banyak yang memberi respon jawaban terhadap pertanyaan yang diberikan oleh guru dan siswapun sudah berani bertanya kepada guru tentang materi yang telah dipelajari. Selanjutnya guru membimbing siswa untuk menyimpulkan pelajaran yang telah dipelajari.

Selama kegiatan pembelajaran, guru melakukan pengamatan pada aktivitas siswa. Hasil pengamatan terhadap aktivitas siswa siklus II disajikan pada Tabel 4. Berdasarkan data yang disajikan pada Tabel 4 aktivitas siswa pada siklus II mengalami kenaikan pada setiap pertemuannya, maupun secara keseluruhannya.Pada pertemuan I memperoleh rata-rata 74,99\%, naik menjadi $77,48 \%$ pada pertemuan II dan naik lagi menjadi $80,22 \%$ pada pertemuan III. Sehingga rata-rata keseluruhannya menjadi $77,77 \%$.Hal ini dapat dilihat dari hasil pengamatan aktivitas siswa yaitu mengerjakan LKS di dalam kelompok sebesar 77,08 \%, aktif berdiskusi di dalam kelompok sebesar 76,04\%, aktif memberikan pertanyaan atau tanggapan sebesar 79,16\%, aktif menjawab atau merespon pertanyaan sebesar $79,16 \%$. Hasil observasi ini menunjukkan bahwa aktivitas siswa pada siklus IIsudah 
memcapai hasil yang diharapkan, langkah-langkah pembelajaran TGT dikarenakan siswa sudah terbiasa belajar walaupun belum seutuhnya. dalam kelompok dan sudah memahami

Tabel 4 Hasil Observasi Aktivitas Siswa Siklus II

\begin{tabular}{|c|c|c|c|c|c|c|}
\hline \multirow{2}{*}{ No } & \multirow{2}{*}{ Indikator } & \multicolumn{3}{|c|}{ Pertemuan $(\%)$} & \multirow{2}{*}{ Jumlah } & \multirow{2}{*}{$(\%)$} \\
\hline & & I & II & III & & \\
\hline 1 & Mengerjakan LKS dalam kelompok & 73,43 & 76,56 & 81,25 & 231,24 & 77,08 \\
\hline 2 & Aktif berdiskusi dalam kelompok & 75 & 75 & 78,12 & 228,12 & 76,04 \\
\hline 3 & $\begin{array}{l}\text { Aktif memberikan pertanyaan / } \\
\text { tanggapan }\end{array}$ & 76,56 & 79,68 & 81,25 & 237,49 & 79,16 \\
\hline 4 & $\begin{array}{l}\text { Aktif menjawab / merespon } \\
\text { pertanyaan }\end{array}$ & 73,43 & 76,56 & 81,25 & 232,24 & 77,41 \\
\hline \multirow[t]{3}{*}{5} & $\begin{array}{l}\text { Mengerjakan tugas yang diberikan } \\
\text { oleh guru }\end{array}$ & 76,56 & 79,68 & 81,25 & 237,49 & 79,16 \\
\hline & Jumlah & 374,98 & 387,42 & 403,12 & 1166,58 & 388,85 \\
\hline & Persentase rata-rata & 74,99 & 77,48 & 80,22 & 77,77 & 77,77 \\
\hline
\end{tabular}

Selain peningkatan pada aktivitas belajar, hasil belajar siswa yang diukur dengan tes juga mengalami peningkatan. Hasil penelitian menunjukkan bahwa ketuntasan hasil belajar siswa secara klasikal pada akhir siklus II memperoleh $62,5 \%$ dari 10 siswa yang memperoleh nilai 70 ke atas dan nilai rata-rata kelas meningkat menjadi 69,38 dibandingkan pada siklus I yang hanya memperoleh 61,25 tapi ini berarti belum mencapai nilai ketuntasan yang telah ditetapkan yaitu 70 . Hasil evaluasi siswa pada siklus II dapat dilihat pada Tabel 5 .

Tabel 5 Hasil tes siswa pada Siklus II

\begin{tabular}{clc}
\hline No. & \multicolumn{1}{c}{ Hal yang Diamati } & Hasil Evaluasi siklus II \\
\hline 1. & Nilai rata-rata kelas & 69,38 \\
2. & Banyak siswa yang tuntas & 10 \\
3. & Banyak siswa yang belum tuntas & 6 \\
4. & Persentase siswa yang tuntas & $62,5 \%$ \\
5. & Persentase siswa yang belum tuntas & $37,5 \%$ \\
\hline
\end{tabular}

Hasil skor yang diperoleh oleh masingmasing kelompok dapat dilihat pada Tabel 6. Tabel 6 memperlihatkan bahwa terdapat penghargaan atas poin perkembangan yang diperoleh setiap masing-masing kelompok dengan predikat Good Team dengan kriteria poin perkembangan 30-40 dan prediket Great Team dengan kriteria poin perkembangan 40-45.

Tabel 6 Hasil tes siswa per kelompok Siklus I

\begin{tabular}{clcccccc}
\hline \multirow{2}{*}{ No. } & Nama & \multicolumn{2}{c}{ Akumulasi Poin Turnamen } & \multirow{2}{*}{ Jumlah } & \multirow{2}{*}{ Rata- rata } & \multirow{2}{*}{ Prediket } \\
& Kelompok & I & II & II & & & \\
\hline 1. & Matahari & 50 & 45 & 37,5 & 132,5 & 44,16 & Great Team \\
2. & Bintang & 30 & 25 & 35 & 90 & 30 & Good Team \\
3. & Bulan & 42,5 & 45 & 40 & 127,5 & 42,5 & Great Team \\
4. & Pelangi & 37,5 & 50 & 40 & 127,5 & 42,5 & Great Team \\
\hline
\end{tabular}


Berdasarkan data yang diperoleh pada siklus II, terlihat bahwa materi operasi hitung bilangan bulat dengan menggunakan model kooperatif tipe TGT sudah memberikan hasil yang lebih baik. Hal ini ditunjukkan dari kegiatan guru yang sudah maksimal dalam mengelola kelas, sehingga mengakibatkan keaktifan siswa yang lebih baik, kerja sama siswa dalam kelompok yang sudah terbina dengan baik karena siswa sudah terbiasa dengan kondisi belajar kelompok.

Hasil refleksi menunjukkan bahwa materi operasi hitung bilangan bulat dengan menggunakan model kooperatif tipe TGT memberikan dampak yang positif terhadap peningkatan hasil belajar, tetapi hasil belajar pada siklus ke II ini masih di bawah ketuntasan klasikal yaitu 70 dan siswa yang memperoleh nilai 70 hanya beberapa siswa saja. Hal ini ditunjukkan dari hasil belajar yang telah dilakukan pada siklus II yaitu sudah 10 siswa yang mencapai nilai ketuntasan dengan persentase ketuntasan $62,5 \%$, hal ini berarti persentase ketuntasan klasikal belum mencapai kriteria yang ditentukan.Dengan demikian, di siklus III akan ditingkatkan kemampuan guru dalam melakukan pembelajaran dengan menggunakan model TGT dengan mengontrol kegiatan siswa agar setiap kegiatan lebih terarah, serta meningkatkan motivasi siswa dengan menggunakan penghargaan berupa alat tulis dan sertifikat.

\section{Siklus III}

Penelitian siklus III dilaksanakan sebanyak 2 kali pertemuan yaitu pada tanggal 22 November 2016 dan 26 November 2016 di kelas VI SDN 058/XI Koto Dumo. Pada penelitian siklus III kegiatan yang dilakukan sama seperti pada siklus I dan II yaitu dibagi dalam 4 (empat) kegiatan yaitu: 1) Perencanaan, Pelaksanaan, 3) Observasi, dan 4) Refleksi.

Perencanaan tindakan adalah kegiatan mempersiapkan segala sesuatu yang akan dilakukan pada setiap siklus. Kegiatan perencanaan dilakukan dengan membuat
Rencana Pelaksanaan Pembelajaran, membuat SkenarioPembelajaran, membuat Lembar Kerja Siswa, membuat Lembar Observasi, dan membuat Lembar Tes.

Pada siklus III ini, kegiatan awal yang dilakukan oleh guru adalah melakukan apersepsi yaitu guru meninjau kembali materi yang telah dipelajari yang berkaitan dengan materi yang akan dipelajari dengan memberikan pertanyaan tentang penjumlahan, pengurangan dan perkalian bilangan bulat. Setelah melakukan apersepsi dan seluruh siswa menanggapi apersepsi tersebut, kemudian guru menjelaskan tujuan pembelajaran dari materi yang akan dipelajari kepada siswa secara singkat. Selanjutnya guru memberikan motivasi kepada siswa dengan cara mengaitkan materi yang akan dipelajari dengan mencontohkan kegiatan yang biasa dilakukan siswa dalam kehidupan sehari-hari dan guru juga langsung memberikan penjelasan tentang petunjuk cara pembelajaran dengan menggunakan model pembelajaran kooperetif tipe TGT dan para siswa hanya mendengarkan penjelasan guru.

Pada kegiatan inti guru membagi siswa menjadi 4 kelompok yang anggota kelompoknya terdiri dari 4 orang dan anggota kelompok dibagi sesuai dengan prestasi. Kemudian guru membimbing siswa untuk mengambil posisi tempat duduk berdasarkan kelompok yang sudah diatur posisinya oleh guru. Guru kemudian menjelaskan materi secara singkat dan pada kegiatan ini setiap anggota dalam kelompok sudah memperhatikan dan menanggapi dengan baik. Selanjutnya guru memberikan tugas kepada kelompok dengan menggunakan lembar kerja siswa yang mana pada setiap kelompok mendapat empat lembar kerja sesuai dengan jumlah siswa dalam kelompok, kemudian setiap anggota kelompok mengerjakan tugas yang telah diberikan dengan saling bekerjasama dan saling membantu untuk menguasai materi, hal ini dilakukan untuk menggali pengetahuan siswa tentang materi yang 
telah dijelaskan dan siswa harus mengumpulkan lembar kerja tersebut sesuai dengan waktu yang telah ditentukan. Pada kegiatan ini sudah terlihat bahwa seluruh siswa mau mengerjakan tugas, tidak ada lagi siswa yang menyalin tugas temannya. Pada tahap ini guru mengamati kinerja siswa dalam kelompoknya masing-masing. Setelah tugasnya selesai dan telah dikumpulkan, kemudian guru memberikan game kepada siswa. Game dilakukan dengan cara siswa dibagi ke dalam 4 meja turnamen yang mana pada setiap meja terdiri dari 1 orang dari masing-masing kelompok sesuai dengan tingkat penguasaan siswa terhadap materi yang sebelumnya telah didiskusikan dan diselesaikan di dalam kelompoknya masing-masing. Dalam setiap meja turnamen disediakan pertanyaanpertanyaan yang harus dijawab oleh siswa dalam kartu-kartu bernomor yang berisi pertanyaan yang harus dijawab oleh siswa, dalam setiap meja turnamen terdapat 6 soal yang harus dijawab oleh siswa, skor yang diperoleh siswa dalam setiap meja kemudian dikumpulkan untuk menentukan kelompok mana yang memperoleh prediket tertinggi. Bagi kelompok yang memperoleh poin tinggi diberi reward berupa alat tulis. Pada tahap ini siswa siswa sudah terbiasa dengan langkah-langkah pembelajaran dengan meggunakan model TGT. Untuk mengetahui tingkat penguasaan siswa terhadap materi yang telah dipelajari guru memberikan evaluasi pada akhir siklus.
Pada kegiatan akhir guru memberikan umpan balik kepada siswa yaitu dengan cara memberikan pertanyaan kepada siswa tentang materi yang telah dipelajari, pada kegiatan ini siswa sudah banyak yang memberi respon jawaban terhadap pertanyaan yang diberikan oleh guru dan siswapun sudah berani bertanya kepada guru tentang materi yang telah dipelajari. Selanjutnya guru membimbing siswa untuk menyimpulkan pelajaran yang telah dipelajari.

Hasil pelaksanaan siklus III sudah sesuai dengan yang diharapkan, karena pada pelaksanaannya para siswa sudah terbiasa dengan kondisi belajar secara kelompok sehingga setiap anggota dalam kelompok sudah serius dalam belajar.Pada saat melaksanakan kegiatan belajar mengajar dengan menggunakan model pembelajaran kooperatif tipe TGT semua siswa sudah memahaminya secara utuh, sehingga pada saat mengerjakan soal yang diberikan dalam lembaran kerja kelompok semua siswa di dalam kelompok ikut berpartisipasi. Pada saat game dan tournamenberlangsung semua siswa mampu menjawab pertanyaan dengan benar. Sedangkan untuk guru, guru sudah mampu mengelola kelas dengan baik dan menjadikan suasana kelas menjadi kondusif.

Selama kegiatan pembelajaran, guru melakukan pengamatan pada aktivitas siswa. Hasil pengamatan terhadap aktivitas siswa siklus III disajikan pada Tabel 4.

Tabel 4 Hasil Observasi Aktivitas Siswa Siklus III

\begin{tabular}{clcccc}
\hline \multirow{2}{*}{ No } & \multirow{2}{*}{ Indikator } & \multicolumn{2}{c}{ Pertemuan (\%) } & \multirow{2}{*}{ Jumlah } & \multirow{2}{*}{$(\%)$} \\
& & I & II & & \\
\hline 1 & Mengerjakan LKS dalam kelompok & 87,5 & 90,62 & 178,12 & 89,06 \\
2 & Aktif berdiskusi dalam kelompok & 84,37 & 89,06 & 173,43 & 86,71 \\
3 & Aktif memberikan pertanyaan / tanggapan & 84,37 & 89,06 & 173,43 & 86,71 \\
4 & Aktif menjawab / merespon pertanyaan & 87,5 & 90,62 & 178,12 & 89,06 \\
5 & Mengerjakan tugas yang diberikan oleh guru & 89,06 & 92,08 & 181,14 & 90,57 \\
& Jumlah & 432,8 & 451,44 & 884,24 & 442,11 \\
& Persentase rata-rata & 86,56 & 90,28 & 88,42 & 88,42 \\
\hline
\end{tabular}

Berdasarkan data dari Tabel 7, aktivitas siswa pada siklus III mengalami kenaikan pada setiap pertemuannya, maupun secara keseluruhannya. Pada 
pertemuan I memperoleh rata-rata $86,56 \%$, naik menjadi $90,28 \%$ pada pertemuan II, sehingga rata-rata keseluruhannya menjadi $88,42 \%$. Hal ini dapat dilihat dari hasil pengamatan aktivitas siswa yaitu mengerjakan LKS di dalam kelompok sebesar $89,06 \%$, aktif berdiskusi di dalam kelompok sebesar 86,71 \%, aktif memberikan pertanyaan atau tanggapan sebesar $86,71 \%$, aktif menjawab atau merespon pertanyaan sebesar 89,06\% dan mengerjakan tugas yang diberikan oleh guru sebesar 90,57\%. Hasil observasi menunjukkan bahwa aktivitas siswa pada siklus III sudah mencapai hasil yang diharapkan, dikarenakan siswa sudah terbiasa belajar dalam kelompok dan sudah memahami langkah-langkah pembelajaran TGT seutuhnya.

Selain peningkatan pada aktivitas belajar, peningkatan juga terjadi pada hasil belajar siswa. Hasil evaluasi siswa pada siklus III dapat dilihat pada Tabel 8.

Tabel 8 Hasil tes siswa pada Siklus III

\begin{tabular}{clc}
\hline No. & \multicolumn{1}{c}{ Hal yang Diamati } & Hasil Evaluasi siklus III \\
\hline 1. & Nilai rata-rata kelas & 80 \\
2. & Banyak siswa yang tuntas & 16 \\
3. & Banyak siswa yang belum tuntas & 0 \\
4. & Persentase siswa yang tuntas & $100 \%$ \\
5. & Persentase siswa yang belum tuntas & $0 \%$ \\
\hline
\end{tabular}

Berdasarkan data pada Tabel 8 , hasil belajar siswa pada siklus III ketuntasan secara klasikalnya sudah mencapai $100 \%$ dan nilai rata-rata kelas meningkat menjadi 80 dari 69,38 pada siklus II. Ini berarti telah melebihi kriteria yang ditetapkan yakni 70.Hal ini menunjukkan penguasaan siswa terhadap materi pembelajaran tergolong tinggi.
Hasil skor yang diperoleh oleh masing-masing kelompok pada siklus III dapat dilihat pada Tabel 9. Tabel 9 memperlihatkan bahwa adanya penghargaan atas poin perkembangan yang diperoleh setiap masing-masing kelompok dengan prediketGood Team dengan kriteria poin 30-40, prediket Great Team dengan kriteria poin 40-45 dan prediket Super Team dengan kriteria poin 45 ke atas.

Tabel 9 Hasil tes siswa per kelompok Siklus I

\begin{tabular}{clccccc}
\hline \multirow{2}{*}{ No } & Nama & \multicolumn{2}{c}{ Akumulasi Skor Turnamen } & \multirow{2}{*}{ Jumlah } & \multirow{2}{*}{ Rata-rata } & \multirow{2}{*}{ Prediket } \\
& Kelompok & I & II & & & \\
\hline 1 & Matahari & 52,5 & 50 & 102,5 & 51,25 & Super Team \\
2 & Bintang & 50,5 & 50 & 100,5 & 50,25 & Super Team \\
3 & Bulan & 40 & 27,5 & 67,5 & 33,75 & Good Team \\
4 & Pelangi & 37,5 & 35 & 72,5 & 36,25 & Good Team \\
\hline
\end{tabular}

Berdasarkan data yang diperoleh pada siklus III, terlihat bahwa materi pembagian dan operasi hitung campuran bilangan bulat melalui model kooperatif tipe TGT memberikan hasil yang sangat baik dan dapat meningkatkan hasil belajar siswa sesuai dengan kriteria ketuntasan yang diharapkan. Tidak ada lagi siswa yang memiliki nilai hasil belajar yang di bawah kriteria ketuntasan belajar dan kegiatan pelaksanaan pengajaran yang dilakukan guru sudah sangat baik. Hal ini ditunjukkan dari kegiatan guru yang dilakukan optimal, sehingga siswa aktif dalam melaksanakan proses pembelajaran sesuai dengan yang diinginkan. kerjasama siswa dalam kelompok yang telah baik dilakukan oleh masing siswa anggota kelompok yang 
dibimbing oleh guru, kemampuan siswa dalam memecahkan masalah dan menyimpulkan materi pelajaran sudah baik sesuai dengan yang diharapkan

Hasil refleksi menunjukkan bahwa materi pokok pembagian dan operasi hitung campuran bilangan bulat melalui model kooperatif tipe TGT memberikan dampak yang positif terhadap peningkatan hasil belajar, hasil belajar pada siklus III ini telah diatas ketuntasan klasikal yaitu $70 \%$ dan seluruh siswa telah memperoleh nilai 70 . Hal ini ditunjukkan dari nilai hasil belajar dan poin perkembangan yang telah dilaksanakan pada siklus III yang dapat di lihat pada lembar lampiran. Berdasarkan hasil, dapat disimpulkan bahwa pelaksanaan pembelajaran matematika pada materi pokok operasi hitung bilangan bulat dengan menggunakan model kooperatif tipe TGT sudah berhasil dilaksanakan.

\section{Analisis Hasil per Siklus}

Berdasarkan hasil penelitian tindakan kelas yang dilakukan di SDN. No. 058/XI Koto Dumo di kelas VI tahun ajaran 2016/2017, dengan pelaksanaan 3 siklus yang mana siklus I terdiri dari 3 kali pertemuan, siklus ke II terdiri dari 3 kali pertemuan, dan siklus ke III terdiri dari 2 kali pertemuan. Hasil penelitian menunjukkan bahwa terjadi perubahan dalam peningkatan hasil belajar siswa yang mendapat nilai lebih dari kriteria yang ditentukan yaitu 70 pada kompetensi dasar melakukan operasi hitung bilangan bulat.

Aspek pertama yang mengalami peningkatan adalah aktivitas belajar siswa. Hasil pengamatan disajikan pada Tabel 10.

Tabel 10 Hasil observasi aktivitas siswa pada Siklus I, II dan III

\begin{tabular}{clccc}
\hline \multirow{2}{*}{ No } & \multicolumn{1}{c}{ Indikator } & \multicolumn{3}{c}{ Siklus (\%) } \\
& & I & II & III \\
\hline 1 & Mengerjakan LKS dalam kelompok & 64,58 & 77,08 & 89,06 \\
2 & Aktif berdiskusi dalam kelompok & 69,26 & 76,04 & 86,71 \\
3 & Aktif memberikan pertanyaan / tanggapan & 65,10 & 79,16 & 86,71 \\
4 & Aktif menjawab / merespon pertanyaan & 64,67 & 77,41 & 89,06 \\
5 & Mengerjakan tugas yang diberikan oleh guru & 70,29 & 79,16 & 90,57 \\
& Jumlah & 333,90 & 388,85 & 442,11 \\
& Persentase & 66,78 & 77,77 & 88,42 \\
\hline
\end{tabular}

Selain peningkatan aktivitas belajar, hasil belajar siswa juga mengalami peningkatan. Peningkatan hasil belajar siswa disajikan pada Tabel 11.

Tabe 11 Analisis hasil evaluasi belajar siswa pada Siklus I, II dan III

\begin{tabular}{clcccc}
\hline No & Siklus & Nilai & $\begin{array}{c}\text { Jumlah Siswa } \\
\text { yang tuntas }\end{array}$ & $\begin{array}{c}\text { Persentase }(\%) \\
\text { Ketuntasan Klasikal }\end{array}$ & $\begin{array}{c}\text { Nilai Rata- } \\
\text { rata Kelas }\end{array}$ \\
\hline 1 & Siklus I & $70-100$ & 8 & 50,00 & 61,25 \\
2 & Siklus II & $70-100$ & 10 & 62,50 & 69,38 \\
3 & Siklus III & $70-100$ & 16 & 100,00 & 80,00 \\
\hline
\end{tabular}

Berdasarkan hasil penelitian, penggunaan model pembelajaran kooperatif tipe TGT pada pembelajaran operasi hitung bilangan bulat dapat meningkatkan hasil belajar siswa kelas VI SDN 058/XI Koto Dumo. Model TGT adalah salah satu tipe atau model pembelajaran kooperatif yang mudah diterapkan, melibatkan aktivitas seluruh siswa tanpa harus ada perbedaan status, melibatkan peran siswa sebagai tutor sebaya dan mengandung unsur permainan. Aktivitas belajar dengan permainan yang dirancang dalam pembelajaran kooperatif model TGT memungkinkan siswa dalam 
belajar lebih rileks di samping menumbuhkan tanggung jawab, kerjasama, persaingan sehat, dan keterlibatan belajar. Dari hasil penelitian tindakan kelas yang dilakukan di SDN. No. 058/XI Koto Dumo, untuk mengatasi kesulitan dalam menyampaikan materi pembelajaran khususnya pada pembelajaran operasi hitung bilangan bulat, yaitu dengan menggunakan model pembelajaran kooperatif tipe TGT, hasil yang dapat dilihat dari penerapan model tersebut diantaranya adalah sebagai berikut:meningkatnya hasil belajar, siswa dapat membangun sendiri pengetahuannya, siswa menemukan langkah-langkah dalam mencari penyelesaian dari suatu materi yang harus dikuasainya, baik secara individu maupun kelompok, dan mengembangkan sikap interaksi yang baik dengan teman sesama anggotanya dalam kelompok.

\section{SIMPULAN}

Berdasarkan hasil penelitian tindakan kelas yang telah dilaksanakan di SDN No.058/XI Koto Dumo melalui beberapa tindakan dari siklus I, II, dan III serta dari seluruh pembahasan analisis yang dilakukan. Hal ini terlihat dari ketuntasan klasikal siswa yang semakin meningkat setiap siklusnya. Pada siklus I ketuntasan klasikal mencapai 50,00\% dengan rata-rata kelas 61,25. Hasil ini meningkat pada siklus II yaitu mencapai $62,50 \%$ dengan rata-rata kelas 69,38 dan kembali meningkat pada siklus III mencapai $100,00 \%$ dengan rata-rata kelas 80,00. Dapat disimpulkan bahwa penggunaan model pembelajaran kooperatif tipe TGT di SDN. No. 058/XI Koto Dumo dapat meningkatkan hasil belajar siswa pada materi pokok operasi hitung bilangan bulat. Berdasarkan hasil, penelitian ini menyarankan sekolah dan guru kelas untuk menerapkan model pembelajaran kooperatif tipe TGT khususnya pada mata pelajaran matematika. Alasannya, pelaksanaan model pembelajaran kooperatif tipe TGT dapat meningkatkan hasil belajar siswa pada materi pokok operasi hitung bilangan bulat.

\section{DAFTAR PUSTAKA}

Nur, A. 2006. Model Pembelajaran Cooperatif. Jakarta: Direktoral Jenderal Pendidikan Tinggi

Rusman. $2010 . \quad$ Model-Model Pembelajaran. Bandung: Rajawali Pers

Solihatin, E., \& Raharjo. 2007. Cooperative learning. Jakarta: Bumi Aksara.

Suprijono, A. 2012. Cooperative Learning Teori dan Aplikasi PAKEM. Yogyakarta: Pustaka Pelajar.

Trianto. 2007. Model-model Pembelajaran Inovatif Berorientasi Kontruktivistik. Jakarta: Prestasi Pustaka. 